\title{
Yield and Woody Biomass Traits of Novel Shrub Willow Hybrids at Two Contrasting Sites
}

\author{
Michelle J. Serapiglia • Kimberly D. Cameron • \\ Arthur J. Stipanovic • Lawrence P. Abrahamson • \\ Timothy A. Volk • Lawrence B. Smart
}

Published online: 31 October 2012

(C) Springer Science+Business Media New York 2012

\begin{abstract}
Shrub willow has great potential as a dedicated bioenergy crop, but commercialization and adoption by growers and end-users will depend upon the identification and selection of high-yielding cultivars with biomass chemistry and quality amenable to conversion to biofuels and bioenergy. In this study, critical traits for biomass production were evaluated among new genotypes of shrub willow produced through hybrid breeding. This study assessed the variation in yield, pest and disease resistance, biomass composition, and wood density in shrub willow, as well as the
\end{abstract}

Electronic supplementary material The online version of this article (doi:10.1007/s12155-012-9272-5) contains supplementary material, which is available to authorized users.

M. J. Serapiglia $\cdot$ K. D. Cameron $\cdot$ L. B. Smart $(\bowtie)$

Department of Horticulture, Cornell University,

New York State Agricultural Experiment Station,

630 West North Street,

Geneva, NY 14456, USA

e-mail: 1bs33@cornell.edu

\section{A. J. Stipanovic}

Department of Chemistry, State University of New York College

of Environmental Science and Forestry,

Syracuse, NY 13210, USA

L. P. Abrahamson

Department of Environmental and Forest Biology, State University

of New York College of Environmental Science and Forestry,

Syracuse, NY 13210, USA

L. P. Abrahamson • T. A. Volk

Department of Forest and Natural Resources Management,

State University of New York College of Environmental

Science and Forestry,

Syracuse, NY 13210, USA

Present Address:

K. D. Cameron

Department of Biology, State University of New York,

Cortland, NY, USA impact of genotypic and environmental factors on these particular phenotypes. Analysis of clonal genotypes established on two contrasting sites in New York State, Tully and Belleville, showed statistical differences by site for all of the traits. The greatest yield was observed at Belleville, NY, for two cultivars, 'Fish Creek' ( $\left.41 \mathrm{Mgha}^{-1}\right)$ and 'Onondaga' $\left(40 \mathrm{Mgha}^{-1}\right)$. Yields of Salix eriocephala genotypes were lowest, and they displayed susceptibility to rust and beetle damage. Variation in cellulose content in the stem biomass was controlled by environmental factors, with the majority of the genotypes displaying greater cellulose content at Belleville compared with Tully. In contrast, wood density was significantly greater at Tully than Belleville, and cellulose content was correlated with wood density. There were no significant correlations between biomass yield and density or any of the composition traits. These trials demonstrate that new genotypes produce improved yield and pest and disease resistance, with diverse compositional traits that can be matched with conversion technologies.

Keywords Beetle damage $\cdot$ Bioenergy $\cdot$ Breeding . Cellulose $\cdot$ Melampsora rust $\cdot$ Wood density

\section{Introduction}

Characterized by rapid juvenile growth, genetically diverse genotypes of shrub willow (Salix spp.) are being domesticated for use as a bioenergy crop in short-rotation coppice systems. The advancement of shrub willow as a bioenergy crop is gaining interest on a worldwide scale, particularly in North America and Europe [1-3]. The environmental and rural developmental benefits associated with shrub willow make it an attractive option for the production of renewable energy and bioproducts [4]. Willows are perennial, outcrossing species in which hybridization can occur in nature. 
They are members of the genus Salix, family Salicaceae, which is strictly dioecious. The natural sexual reproductive habit of shrub willow highlighted by out-crossing of longlived dioecious plants of multiple overlapping generations within large populations has allowed the species to maintain high levels of genetic diversity and heterozygosity within the population as well as between populations [5]. Sampling of natural populations has provided a large gene pool of variation for potential genetic improvement.

The domestication and genetic improvement of Salix for bioenergy began in Sweden in the mid-1970s spurring willow research in Ontario, Canada, soon after leading to research and development in the United States in 1986 [6-8]. In the mid-1990s, breeding of shrub willow began in New York State for the development of an improved crop suitable for the Northeastern and Midwest U.S. Many European cultivars were imported and tested, but it was soon discovered that these were susceptible to damage by potato leafhopper (Empoasca fabae Harris). The breeding of shrub willow in New York State has produced genotypes through intraspecific crosses as well as novel species hybrids through controlled interspecific hybridization that are more suitable to the environment in North America [8].

Major traits for shrub willow biomass production include biomass yield, pest and disease resistance, wood density, and biomass composition. Even though biomass yield may be considered the most critical trait, it is necessary to understand how pest and disease damage as well as wood density and composition will impact economic yield. As more emphasis is placed on using willow as a feedstock for biofuels, the chemical composition of the biomass will become more important, since the composition has been demonstrated to have impact on conversion efficiency [9]. Ideally, selection of high-yielding novel cultivars will generate diversity of biomass chemical composition that can be matched to a particular conversion technology [10-12]. Therefore, one goal of our breeding program is to develop pedigrees with transgressive segregation of compositional traits coupled with high yield.

Wood formation through the successive seasonal growth of secondary xylem is highly responsive to environmental influences, in addition to the underlying genetic control of lignocellulosic deposition [13]. Nitrogen fertilization studies with poplar have indicated strong effects on wood properties, including increased cellulose content, reduced lignin, reduced density, and thicker cell walls [14-16]. Site interactions and environmental factors have also been documented to have significant impacts on wood density [17-19]. There is also increasing evidence that suggests a strong inverse relationship between growth and lignin content $[20,21]$. These results imply that selection for improved growth rates would concomitantly result in reduced lignin content, a trait that is considered highly desirable for pulp and paper production and for the biological production of biofuels, while feedstocks with greater lignin yield more energy in thermochemical systems $[22,23]$. Biomass yield is controlled by carbon sequestration abilities, carbon allocation, and the availability of nitrogen, as the most limiting nutrient for growth and carbon sequestration [24]. The interrelationship among these wood properties and yield are of particular interest in this study, as well as the level of observed variation among the selected genotypes.

Additional interests of this study were to characterize the incidence of willow leaf rust (Melampsora spp.) and beetle damage on the willow genotypes to determine if incidence of rust and beetle damage impacts yield potential in these particular genotypes. Willow rust is a very important threat to willow [25-28]. The fungus attacks leaf tissue, leading to premature defoliation, subsequently having an impact on carbon sequestration and biomass growth [29]. Chrysomelid beetles also cause extensive damage to willow in the U.S. and Europe [30-32]. In North America, imported willow beetle (Plagiodera versicolora Laicharting), native willow beetle (Calligrapha multipunctata), and the Japanese beetle (Popillia japonica Newman) are the most widespread beetle pests on willow [33, 34]. Feeding on leaf tissue can have a significant impact on yield in susceptible genotypes [32]. We hypothesize that novel species hybrids involving species resistant to rust and beetles, such as Salix miyabeana, will produce high-yielding resistant progeny.

This project focused on the characterization of shrub willow genotypes that were produced in 1998 and 1999, as well as parental reference genotypes and genetically diverse accessions obtained from naturally established stands within the Northeastern U.S. For willow, breeding strategies benefit from maximizing the phenotypic variation in progeny families to increase the probability of identifying exceptional individuals. With clonal propagation, scale-up of elite individuals is done asexually and does not require annual production of large, stable seed stocks with high population means for quantitative traits. However, there is ample evidence of genotype by environment interactions from both willow and poplar breeding. To evaluate the genotypic and environmental influences on important biomass traits, 18 genotypes were selected for evaluation in replicated yield trials established on two sites in Tully and Belleville, NY. The objectives of this study were: (1) to report on the breeding and selection of genotypes representing novel species hybrids of shrub willow and their biomass growth potential on two NY sites; (2) to quantify incidence of rust and beetle damage among these novel genotypes on sites with varying pressure; (3) to describe variation in wood properties among these novel genotypes in relation to soil and environmental conditions; (4) to examine the relationship between wood properties and biomass yield. 


\section{Materials and Methods}

\section{Breeding and Selection of Novel Willow Genotypes}

Willow breeding was performed in 1998 and 1999 by Richard Kopp producing over 2,000 progeny from more than 100 unique crosses, including interspecific crosses of Salix sachalinensis $\times$ Salix purpurea, Salix viminalis $\times$ S. miyabeana, $S$. purpurea $\times S$. miyabeana, and $S$. sachalinensis $\times S$. miyabeana, as well as intraspecific crosses of $S$. purpurea and Salix eriocephala. The breeding strategy was to produce new genotypes with improved yield and pest and disease resistance compared with the natural accessions and cultivars obtained from the Louis Zsuffa breeding program in Canada [35]. The progeny from successful crosses in 1998 and 1999 were planted in non-replicated Family Screening Trials at LaFayette Road Experiment Station, Syracuse, NY. Each trial was coppiced after the first growing season and then was measured each of the two following growing seasons for total stem area, height, and incidence of pests and diseases. The best individuals from these data were scaled-up and tested in selection trials planted in 2001 and 2002 at the Tully Genetics Field Station in Tully, NY. The replicated, multi-plant plots in these trials were measured for growth traits and evaluated for pest and disease resistance over multiple years. Based on their growth and form, 13 genotypes were selected to test further in yield trials located in Tully and Belleville, NY, together with four reference cultivars and one natural accession used as a parent (Table 1). Of the 18 genotypes in these trials, four ('SV1,' 'SX61,' 'SX64,' and 'S25') are considered reference genotypes. They have been used as parents for many crosses and have been included repeatedly in selection and yield trials. The genotype 94001 (S. purpurea) was collected in 1994 in NY and has also been used as a parent in several crosses. These replicated yield trials were planted to test the yield potential and impact of contrasting environmental conditions on the performance of specific willow genotypes.

\section{Site Characteristics}

Trials were established in Tully, NY, at the Tully Genetics Experiment Station, State University of New York College of Environmental Science and Forestry $\left(42^{\circ} 47^{\prime} 30^{\prime \prime} \mathrm{N}\right.$, $\left.076^{\circ} 07^{\prime} 30^{\prime \prime} \mathrm{W}\right)$, and in Belleville, NY, at Belleville-

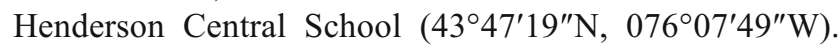
Mean annual precipitation and mean annual air temperature fall within similar ranges for both locations. The soil at Tully is a well-drained to excessively well-drained Palmyra gravelly loam with a depth to water table of greater than $203 \mathrm{~cm}$ [36]. The soil at the Belleville site is well-drained to moderately well-drained Galway silt loam with a depth to seasonal high water table ranging from 46 to $102 \mathrm{~cm}$ and a depth to bedrock of 51-102 cm [37]. Soil samples were taken from all four replicate plots at each site, Belleville, NY, and Tully, NY. Soil probes were used to collect soil cores to a depth of $25 \mathrm{~cm}$. A total of eight cores per block were collected and pooled, and the homogenized sample for each block was analyzed by the Cornell Nutrition Analysis Laboratory (Ithaca, NY). Mean values were calculated from the four samples (Table 2). Precipitation records for the two locations were obtained from the
Table 1 Shrub willow genotypes studied in the 2005 Tully and Belleville yield trials

\begin{tabular}{lll}
\hline Clone ID/cultivar epithet & Species/pedigree & Source \\
\hline SV1 & S. $\times$ dasyclados & University of Toronto \\
SX61 & S. sachalinensis & University of Toronto \\
SX64 & S. miyabeana & University of Toronto \\
S25 & S. eriocephala & University of Toronto \\
94001 & S. purpurea & Blossvale, NY \\
$9832-49$ & S. eriocephala $(95306) \times$ S. eriocephala $(95061)$ & Bred in 1998 \\
$9837-77$ & S. eriocephala $(95311) \times$ S. eriocephala $(95061)$ & Bred in 1998 \\
Fish Creek & S. purpurea $(94006) \times$ S. purpurea $(94001)$ & Bred in 1998 \\
Onondaga & S. koriyanagi $($ SH3) $\times$ S. purpurea $(94002)$ & Bred in 1999 \\
Allegany & S. koriyanagi $($ SH3) $\times$ S. purpurea $(95058)$ & Bred in 1999 \\
Oneonta & S. purpurea $(94006) \times$ S. miyabeana $($ SX64) & Bred in 1998 \\
Oneida & S. purpurea $(94006) \times$ S. miyabeana $($ SX67) & Bred in 1999 \\
Millbrook & S. purpurea $(95026) \times$ S. miyabeana $($ SX64) & Bred in 1999 \\
Sherburne & S. sachalinensis $($ SX61) $\times$ S. miyabeana $($ SX67) & Bred in 1998 \\
Canastota & S. sachalinensis $($ SX61) $\times$ S. miyabeana $($ SX64) & Bred in 1999 \\
Otisco & S. viminalis $($ SV2) $\times$ S. miyabeana $($ SX64) & Bred in 1999 \\
Tully Champion & S. viminalis $($ SV2) $\times$ S. miyabeana $($ SX67) & Bred in 1999 \\
Owasco & S. viminalis $($ SV7) $\times$ S. miyabeana $($ SX64) & Bred in 1999 \\
\hline
\end{tabular}


Table 2 Site characteristics for Tully, NY, and Belleville, NY

\begin{tabular}{|c|c|c|}
\hline Site characteristics & Tully & Belleville \\
\hline Latitude & $42^{\circ} 47^{\prime} 30^{\prime \prime} \mathrm{N}$ & $43^{\circ} 47^{\prime} 19^{\prime \prime} \mathrm{N}$ \\
\hline Longitude & $76^{\circ} 07^{\prime} 30^{\prime \prime} \mathrm{W}$ & $76^{\circ} 7^{\prime} 49^{\prime \prime} \mathrm{W}$ \\
\hline Elevation (m) & 396 & 139 \\
\hline Soil type & Palmyra & Galway \\
\hline $\begin{array}{l}2005 \text { Precipitation } \\
\text { (May-August; cm) }\end{array}$ & 32.23 & 36.22 \\
\hline $\begin{array}{l}2006 \text { Precipitation } \\
\text { (May-August; cm) }\end{array}$ & 65.63 & 40.41 \\
\hline $\begin{array}{l}2007 \text { Precipitation } \\
\text { (May-August; cm) }\end{array}$ & 32.46 & 21.77 \\
\hline $\begin{array}{l}2008 \text { Precipitation } \\
\text { (May-August; cm) }\end{array}$ & 34.11 & 57.12 \\
\hline Phosphorus (mg kg$\left.{ }^{-1}\right)^{*}$ & $2.36 \pm 0.13$ & $7.80 \pm 1.51$ \\
\hline Potassium $\left(\mathrm{mg} \mathrm{kg}^{-1}\right)^{*}$ & $77.18 \pm 2.53$ & $109.42 \pm 9.55$ \\
\hline Magnesium (mg kg$\left.{ }^{-1}\right)^{*}$ & $71.59 \pm 5.81$ & $51.83 \pm 1.90$ \\
\hline Calcium $\left(\mathrm{mg} \mathrm{kg}^{-1}\right)^{*}$ & $919.30 \pm 49.14$ & $2888.47 \pm 356.43$ \\
\hline Iron $\left(\mathrm{mg} \mathrm{kg}^{-1}\right) *$ & $34.61 \pm 1.74$ & $3.95 \pm 0.61$ \\
\hline Aluminum (mg kg$\left.)^{-1}\right)^{*}$ & $119.28 \pm 7.04$ & $23.15 \pm 4.43$ \\
\hline Manganese $\left(\mathrm{mg} \mathrm{kg}^{-1}\right)$ & $32.14 \pm 2.40$ & $25.88 \pm 2.50$ \\
\hline Zinc $\left(\mathrm{mg} \mathrm{kg}^{-1}\right)$ & $0.74 \pm 0.08$ & $0.60 \pm 0.04$ \\
\hline Nitrate $\left(\mathrm{mg} \mathrm{kg}^{-1}\right)^{*}$ & $0.14 \pm 0.14$ & $3.92 \pm 1.31$ \\
\hline Ammonium (mg kg$\left.)^{-1}\right)^{*}$ & $15.92 \pm 0.77$ & $12.44 \pm 0.96$ \\
\hline $\mathrm{pH}^{*}$ & $4.99 \pm 0.03$ & $6.49 \pm 0.11$ \\
\hline Buffer pH* & $4.97 \pm 0.12$ & $6.15 \pm 0.10$ \\
\hline$\%$ Organic matter & $3.23 \pm 0.14$ & $3.25 \pm 0.25$ \\
\hline
\end{tabular}

*Soil properties in bold were significantly different by site

Northeast Regional Climate Center from weather stations in Tully, NY, and Lacona, NY.

\section{Trial Establishment and Harvest}

The two site locations were prepared by moldboard plowing and cross-disking prior to planting. The Tully location was fallow, and the Belleville field was cultivated in corn the year prior to planting. The same suite of clones were handplanted at the two sites in May 2005 using $25-\mathrm{cm}$ cuttings in double-row spacing at a density of 15,000 plants ha ${ }^{-1}$. Each genotype was planted in plots with three double-rows and 13 plants per row, for 78 plants per plot. Each trial was a randomized complete block design with four blocks per site. Preemergent herbicides, oxyfluoren (Goal 2XL, $1.1 \mathrm{~kg}$ ai ha ${ }^{-1}$ ) and simazine (Princep, $2.2 \mathrm{~kg} \mathrm{ai} \mathrm{ha}^{-1}$ ), were applied immediately after planting. In July 2005 , the sites were hand-weeded, and herbicides were spot-applied. In January 2006, the trials were coppiced at the end of the first growing season and measured for survival. In June 2006, at the beginning of the first growing season post-coppice, the trials were fertilized with urea at $100 \mathrm{kgN} \mathrm{ha}^{-1}$. After the third post-coppice season in December 2008, aboveground biomass was harvested.
Biomass yield was measured by weighing all of the stems cut from the middle 18 plants in each plot. Yields were not adjusted based on plant survival but rather scaled up based on plot area. A sub-sample from three representative stems was collected, dried, and weighed to determine moisture content at harvest, which allowed estimation of dry weights. In addition, for biomass compositional analysis, all the stems from two plants from outside the measurement plot were harvested and chipped from only the first three blocks (the fourth block was not measured for composition). The chips were dried to a constant weight at $65^{\circ} \mathrm{C}$ and ground in a Wiley mill through a 20 -mesh screen. An additional $25-\mathrm{cm}$ section was collected from the middle of a typical canopy stem of one plant in each plot to determine wood density by volumetric displacement [38].

\section{Survey of Rust Incidence and Beetle Damage}

Surveys for beetle damage and incidence of rust were performed three times per year during the 2006, 2007, and 2008 growing seasons. Beetle damage was assayed as percent defoliation determined by the percentage of total leaf area consumed on a subset of four main canopy stems from one plant per plot and averaged for all replicates and years.

Disease ratings for rust and area under the disease progress curves (AUDPC) were based on the midpoint value of percent incidence observed on ten randomly selected leaves from one stem from one plant in each plot. Rust incidence on each leaf was rated using the 'Rust Assessment Key' from McCracken and Dawson [39]. Area under the disease progress curve was calculated according to the formula: $\sum\left(\left[\left(x_{i}+x_{i-1}\right) / 2\right]\left(t_{i}-t_{i-1}\right)\right)$ where $x_{i}$ is the rating at each evaluation time and $\left(t_{i}-t_{i-1}\right)$ is the time between evaluations in days. Since the incidence of rust was different for the 3 years measured, years were analyzed separately and not averaged together across years.

\section{High-Resolution Thermogravimetric Analysis}

Willow biomass samples were analyzed using a Thermogravimetric Analyzer 2950 (TA Instruments, New Castle, DE) with the TA Universal Analysis 2000 software according to Serapiglia et al. [10]. Each field replicate sample from the first three blocks of the trial was analyzed once and the means determined for each trial. Traits obtained from this analysis were percent cellulose, hemicellulose, lignin, and ash content as a proportion of the total biomass. The method used was 'high-resolution dynamic' with a heating rate of $20{ }^{\circ} \mathrm{C} \mathrm{min}{ }^{-1}$, a final temperature of $600{ }^{\circ} \mathrm{C}$, a resolution of 4.0 , and a sensitivity value of 1.0 . The electrobalance was purged with nitrogen at a flow rate of $44 \mathrm{~mL} \mathrm{~min}{ }^{-1}$, and the furnace was purged with compressed air with a flow rate of 


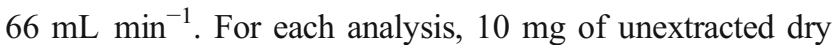
tissue was used. Each thermogram generated was individually analyzed for cellulose, hemicellulose, and lignin by identifying the thermal events associated with each compound on the derivative curve according to Serapiglia et al. [10].

\section{Statistical Analysis}

All statistical analyses were performed using $\mathrm{SAS}^{\circledR}$ version 9.2 at a critical $\alpha$ level of 0.05 [40]. Normality of distribution for each trait was checked by Kolmogorov $D$ and Shapiro-Wilk's statistic $W$ and graphically by normalprobability plots and histograms using SAS PROC UNIVARIATE. No transformation of the data was required. Only for yield data were outliers removed. For 94001 and 'SV1,' the weight of one replicate was two- to three-fold greater than those of the other replicates, probably due to procedural error during weighing, and thus they were removed before further analysis.

PROC MIXED was used to perform analysis of variance, and restricted maximum likelihood method was used to estimate the significant effects of the two factors, site and genotype, and to calculate the variance components for the random effect, block nested within site. When a significant difference $(P<0.05)$ was observed, Tukey's mean studentized range test was used for pairwise comparisons among genotypes at each site using PROC GLM. PROC CORR was used to identify any significant correlations among variables obtained in this study except beetle damage. Principle component analysis (PCA) was performed using PROC FACTOR to analyze all data for all traits except beetle damage. Correlations and PCA were performed on only three replicates since compositional data were only performed on the first three replicates. In addition to the above analyses, a separate independent model was created to analyze taxa using PROC MIXED where site and taxon were the fixed effects and block nested within site was the random effect. Genotype and taxon were kept independent of each other because combining both taxon and genotype into the same model led to nesting of genotype within taxon, preventing comparison of all genotypes with each other.

\section{Results}

\section{Biomass Yield}

For six of the 18 genotypes examined, biomass yield was significantly greater at the Belleville location, compared with Tully (Fig. 1; Table 3). There was not a significant difference in survival between the two sites (Supplemental Table 1). For yield, the main effect of location was not significantly different, but genotype and the interaction between the two main effects were significantly different $(p$ value $<0.0001$;
Fig. 1 Dry biomass yield $($ mean + SE) after 3 years of growth at Tully and Belleville, NY. Asterisks indicate significant differences between the two sites at $p=0.05$

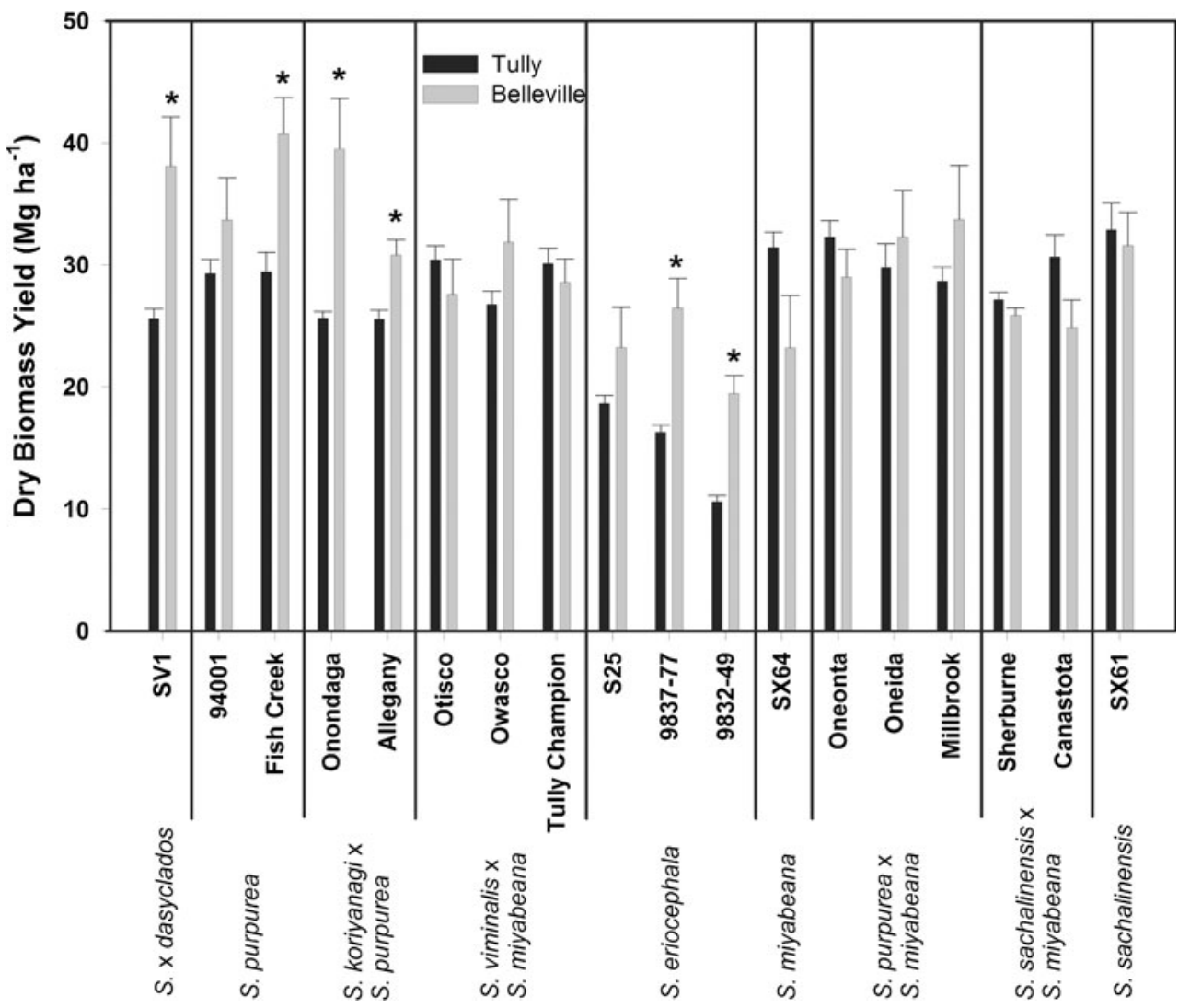


Table 3 Biomass yield in oven dry tonnes per hectare per year for each genotype at each location, Tully, NY, and Belleville, NY

\begin{tabular}{llll}
\hline Cultivar* & $\begin{array}{l}\text { Belleville yield } \\
\mathrm{Mg} \mathrm{ha}^{-1} \text { year }^{-1}\end{array}$ & Cultivar & $\begin{array}{l}\text { Tully yield } \\
\mathrm{Mg} \mathrm{ha}^{-1} \text { year }^{-1}\end{array}$ \\
\hline Fish Creek & 13.58 & SX61 & 10.95 \\
Onondaga & 13.17 & Oneonta & 10.77 \\
SV1 & 12.70 & SX64 & 10.48 \\
Millbrook & 11.24 & Canastota & 10.23 \\
94001 & 11.23 & Otisco & 10.14 \\
Oneida & 10.77 & Tully Champion & 10.04 \\
Owasco & 10.62 & Oneida & 9.94 \\
SX61 & 10.53 & Fish Creek & 9.81 \\
Allegany & 10.28 & 94001 & 9.77 \\
Oneonta & 9.67 & Millbrook & 9.56 \\
Tully & 9.53 & Sherburne & 9.06 \\
Champion & & & \\
Otisco & 9.20 & Owasco & 8.93 \\
9837-77 & 8.82 & Onondaga & 8.55 \\
Sherburne & 8.62 & SV1 & 8.54 \\
Canastota & 8.30 & Allegany & 8.52 \\
S25 & 7.74 & S25 & 6.22 \\
SX64 & 7.73 & $9837-77$ & 5.43 \\
$9832-49$ & 6.48 & $9832-49$ & 3.54 \\
\hline
\end{tabular}

* Ranked according to yield at each site. Annual production was calculated by dividing mean trial yields by 3

Supplemental Table 2). Pair-wise comparisons showed 'SV1,' 'Onondaga,' 'Fish Creek,' 'Allegany,' 9837-77, and 983249 had significantly greater yield at Belleville compared with Tully. The four genotypes with the greatest yield at Belleville were 'Fish Creek,' 'Onondaga,' 'SV1,' and 'Millbrook,' with yields ranging from 13.6 to $11.2 \mathrm{Mg}$ $\mathrm{ha}^{-1}$ year $^{-1}$ (Table 3). At Tully, the greatest yields were from 'SX61,' 'Oneonta,' 'SX64,' and 'Canastota,' ranging from 11.0 to $10.2 \mathrm{Mg} \mathrm{ha}^{-1}$ year $^{-1}$. Analysis by taxa also showed significant differences by taxon, location, and an interaction (Supplemental Table 3). In pair-wise comparisons, Salix koriyanagi $\times S$. purpurea, S. eriocephala, and Salix $\times$ dasyclados were significantly different by site. Total biomass after 3 years of growth was greatest at Belleville, with an average yield of $29.8 \mathrm{Mg} \mathrm{ha}^{-1}$, compared with Tully, with an average yield of $26.7 \mathrm{Mg} \mathrm{ha}^{-1}$. The variation in yield observed among the genotypes was greater at Belleville with a \%CV of 24.84 (Table 4).

Incidence of Rust

Observed incidence of rust was most prevalent on the $S$. eriocephala genotypes ('S25,' 9837-77, and 9832-49; Fig. 2). There was a low incidence of rust on $S$. purpurea genotypes in 2006 but not in 2007 or 2008. No other genotypes displayed visual signs of rust over the three growing
Table 4 Phenotypic variation observed for all traits among 18 willow genotypes from two different sites

\begin{tabular}{|c|c|c|c|c|}
\hline \multirow[b]{2}{*}{ Phenotype } & \multicolumn{2}{|l|}{ Tully } & \multicolumn{2}{|l|}{ Belleville } \\
\hline & Mean \pm SE & $\% \mathrm{CV}$ & Mean \pm SE & $\% \mathrm{CV}$ \\
\hline$\%$ Cellulose & $41.01 \pm 0.22$ & 4 & $42.34 \pm 0.26$ & 4 \\
\hline$\%$ Hemicellulose & $32.32 \pm 0.14$ & 3 & $31.94 \pm 0.15$ & 3 \\
\hline$\%$ Lignin & $22.34 \pm 0.14$ & 5 & $22.04 \pm 0.12$ & 4 \\
\hline$\%$ Ash & $1.14 \pm 0.09$ & 57 & $1.93 \pm 0.15$ & 58 \\
\hline Wood density $\left(\mathrm{g} \mathrm{cm}^{-3}\right)$ & $0.43 \pm 0.01$ & 8 & $0.40 \pm 0.01$ & 12 \\
\hline Yield $\left(\mathrm{Mgha}^{-1}\right)$ & $26.74 \pm 0.73$ & 23 & $29.84 \pm 0.87$ & 25 \\
\hline Rust 2006 (AUDPC) & $238.30 \pm 55.70$ & 198 & $243.03 \pm 76.04$ & 265 \\
\hline Rust 2007 (AUDPC) & $2.78 \pm 1.04$ & 318 & $3.86 \pm 1.60$ & 352 \\
\hline Rust 2008 (AUDPC) & $121.32 \pm 36.95$ & 258 & $32.60 \pm 13.41$ & 349 \\
\hline$\%$ Beetle damage & $13.31 \pm 1.52$ & 97 & $15.78 \pm 1.51$ & 81 \\
\hline
\end{tabular}

seasons except for a mild incidence observed on 'Allegany' in 2006 and 2008.

\section{Beetle Damage}

Beetle damage was observed on all genotypes at both sites (Fig. 3). Significant differences among genotypes were observed, as well as a significant interaction between genotype and site (Supplemental Table 2). There was an interaction between taxon and location (Supplemental Table 3), and pairwise comparisons indicated that only the $S$. viminalis $\times$ S. miyabeana genotypes ('Otisco,' 'Owasco,' and 'Tully Champion') had significantly greater beetle damage at Belleville than at Tully. 'SV1' and 9832-49 had the greatest beetle damage at Belleville, and 9837-77 and 9832-49 had the greatest damage at Tully.

\section{Biomass Composition}

Cellulose composition was significantly different by both genotype and location; however, the interaction was not significant (Fig. 4; Supplemental Table 2). Cellulose content at Belleville across all the clones averaged $42.3 \% \pm 0.3$ and was significantly greater than cellulose content at Tully with an average of $41.0 \% \pm 0.2$ ( $p$ value 0.028 ). The greatest cellulose content was observed in 'Tully Champion' and 9837-77 at Belleville. There was no significant difference by site for hemicellulose or lignin content, but there was a significant interaction between genotype and site. For all three biomass components, the variation among the genotypes was low, with $\% \mathrm{CV}$ below 5 (Table 4 ). Across both sites and genotypes, cellulose content ranged from $38.7 \%$ to $44.5 \%$, whereas lignin ranged from $20.9 \%$ to $24.1 \%$. Hemicellulose showed the least variation, $30.1 \%$ to $33.6 \%$. Analysis of the data grouped by taxa showed a 
Fig. 2 Rust incidence (mean+ $\mathrm{SE}$ ) on shrub willow genotypes at Tully and Belleville, NY, reported as area under the disease progress curve (AUDPC). Asterisks indicate significant differences between the two sites at $p=0.05$. a Rust incidence in 2006 , b rust incidence in 2007, and c rust incidence in 2008
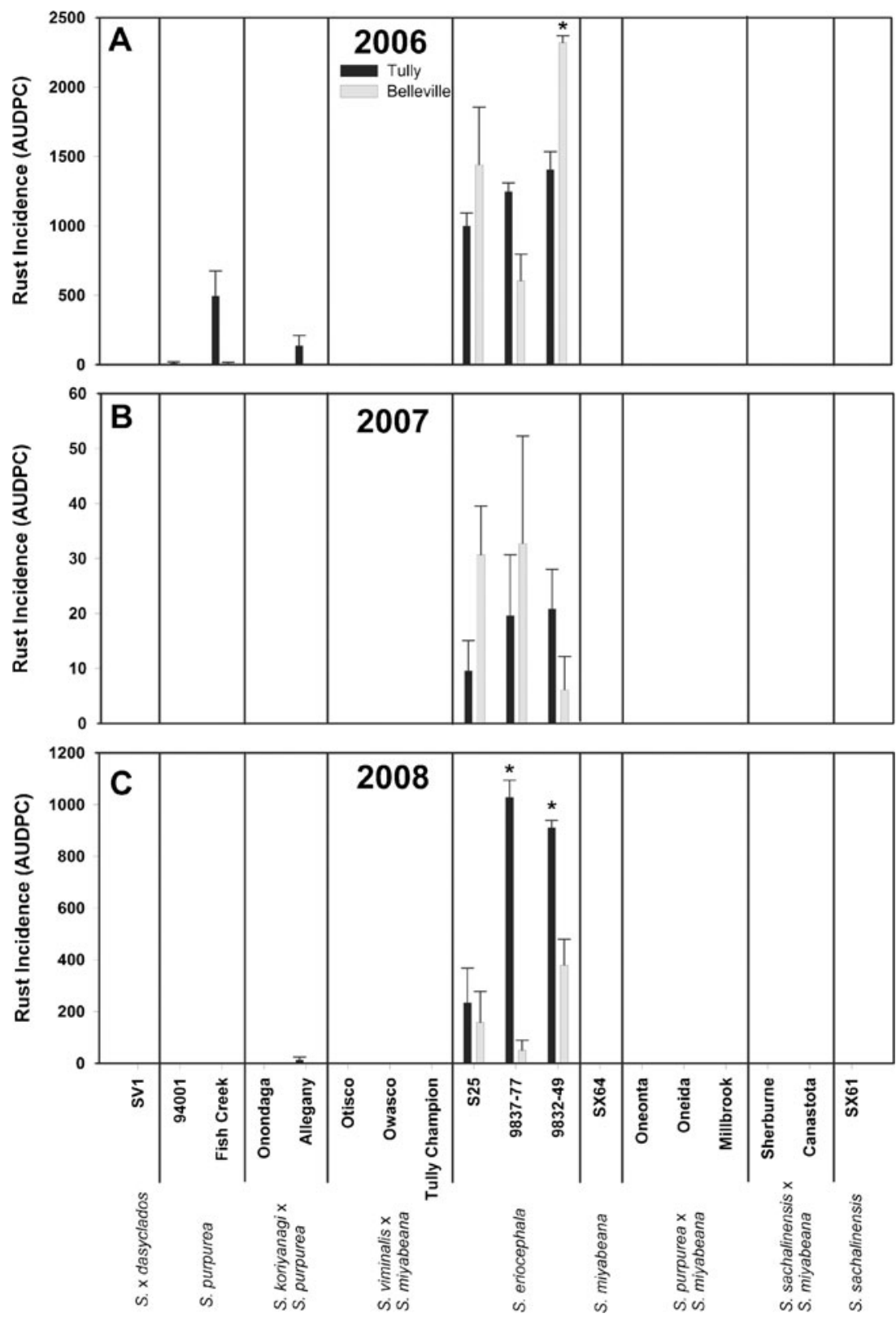

significant interaction between taxon and location for lignin content only (Supplemental Table 3). Based on pair-wise comparisons performed by Tukey's studentized range test, only $S$. viminalis $\times S$. miyabeana genotypes ('Otisco' and 'Tully Champion') had significantly greater lignin content at Tully.

Ash content was significantly greater at Belleville (Fig. 4). Ash content was significantly different by genotype and location, with an interaction between genotype and location ( $p$ value $<0.0001$; Supplemental Table 2). Pair-wise comparisons showed, 'SV1,' 'Allegany,' 'S25,' 9832-49, 'Oneida,' 'Millbrook,' and 'SX61' to have significantly greater ash content at Belleville compared with Tully. In some cases, ash content was over two-fold greater at Belleville. When grouped by taxa, S. sachalinensis, S. miyabeana, and $S$. sachalinensis $\times S$. miyabeana had the greatest ash content compared with the other taxa in this study, and S. purpurea had the lowest ash content. The variability of ash content among the willow genotypes was relatively high, with $\% \mathrm{CV}$ around $57 \%$, regardless of location (Table 4).

\section{Wood Density}

Wood density was significantly different between the two sites (Fig. 5) and by genotype, but the genotype by site interaction was not significant (Supplemental Table 2). Mean wood density at the Tully location was $0.43 \mathrm{~g} \mathrm{~cm}^{-3}$ and at Belleville was $0.40 \mathrm{~g} \mathrm{~cm}^{-3}$ (LSD $\left.=0.006\right)$. 'SV1' had the greatest density at each site among all genotypes $\left(0.45\right.$ and $\left.0.47 \mathrm{~g} \mathrm{~cm}^{-3}\right)$. Analysis by taxa was also significantly different with no interaction by site (Supplemental Table 3). 
Fig. 3 Beetle damage (mean + SE) observed on shrub willow genotypes at both Tully and Belleville, NY. Asterisks indicate significant differences between the two sites at $p=0.5$

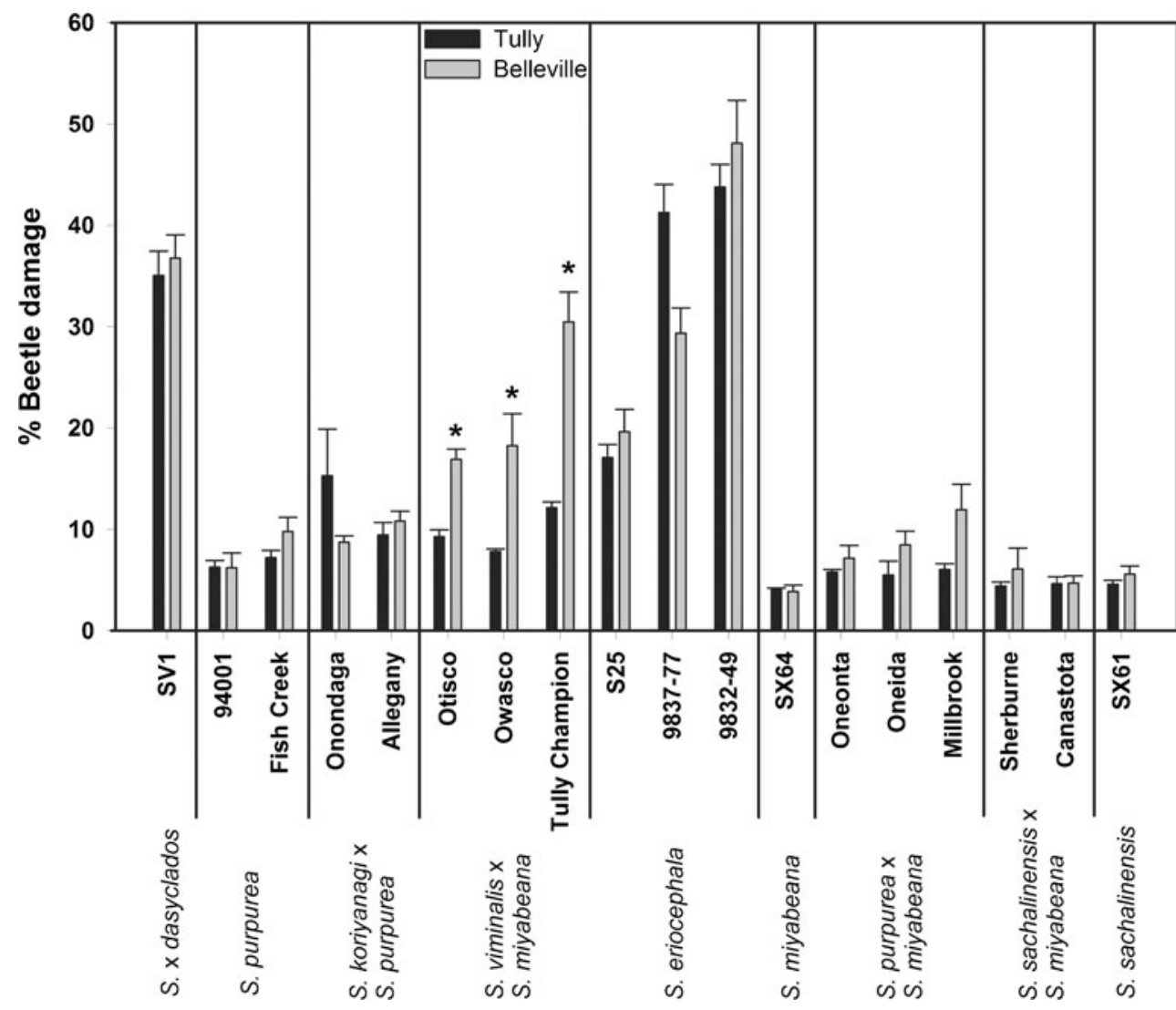

\section{Correlations Between Traits}

There were correlations observed between cellulose content and ash content and wood density at both sites (Table 5). Ash content correlated with density only at Tully. There was no correlation between yield and any of the wood traits. Yield was correlated negatively with rust incidence at both sites, but those correlations were stronger at Tully than at Belleville. Principle component analysis determined that for Tully $53 \%$ of the variance was explained by PC1 consisting of yield and rust. The same PC was identified at Belleville and explained $43 \%$ of the variance.

\section{Discussion}

\section{Biomass Growth Potential}

Of the 18 genotypes planted in the 2005 Yield Trials in Tully and Belleville, NY, 13 were produced through controlled pollinations conducted in 1998 and 1999. The performance of these individuals at the two trial sites provides insight into factors that may be limiting growth potential and can guide future selection of new progeny. At the Belleville location, new cultivars, 'Fish Creek' and 'Onondaga,' ranked higher in yield than the top reference genotype, 'SV1' (Table 3). At the Tully site, 'SX61' was the top-yielding genotype, even though many of the new genotypes had outperformed 'SX61' in the 2002 Selection Trial located in Tully, NY [8]. Both 'Oneonta' and 'Canastota' were in the top four, but did not surpass the yield of 'SX61.' Prior trials of the new willow genotypes produced in 1998 and 1999 have yielded $38 \%$ more biomass than the older reference cultivars [41]. In one trial, the top individuals among the 1999 progeny had over a $120 \%$ increase in biomass yield relative to the reference cultivar, 'SV1' [7]. Based on these current yield data, improvements in the selection process for yield are still warranted. The current yield data do suggest a genotype $\times$ environment interaction for biomass yield, which suggests that early selection on multiple contrasting sites is necessary. For commercialization purposes, elite high-yielding willow genotypes identified in selection trials must be able to maintain exceptional performance across a diversity of sites and environmental conditions or can be selected for superior performance in specific environments.

Our results reveal specific willow genotype $\times$ site interactions for many of the phenotypic traits analyzed in this study. However, some genotypes are plastic with regard to environment. Most of the 18 genotypes used in this study were able to produce high yield (above $9 \mathrm{Mg} \mathrm{ha}^{-1}$ year $^{-1}$ ) across both sites, regardless of the differences in soil conditions, particularly the $S$. miyabeana hybrids (Fig. 1). However, there were six genotypes that had significantly greater yield at Belleville, indicating that factors in Tully were 

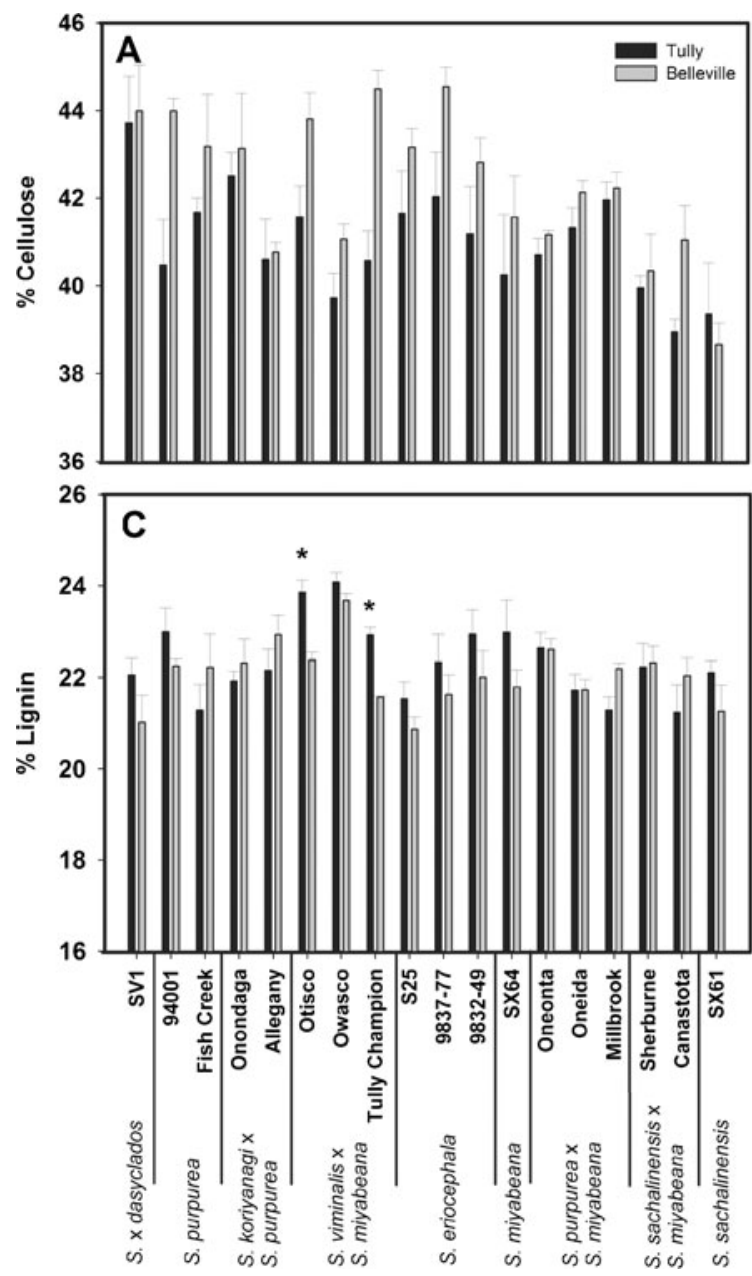

Fig. 4 Willow composition as percent dry weight (mean $+\mathrm{SE})$ at harvest after 3 years of growth at Tully and Belleville, NY, as determined by high-resolution thermogravimetric analysis. Asterisks

limiting growth potential. It is clear that the two $S$. eriocephala genotypes, 9837-77 and 9832-49, had more rust damage during the growing season in 2008 (Fig. 2), and with a strong inverse relationship between rust incidence and yield, the lower yields at Tully for these two could be due to rust damage. The genotypes 'SV1,' 'Fish Creek,' 'Onondaga,' and 'Allegany' all had significantly greater yield at Belleville, but no differential damage associated with rust incidence or beetle damage was observed between the sites for these genotypes. Less favorable conditions at Tully, such as low $\mathrm{pH}$, low nutrient availability, and/or lower water availability could be having an impact on these four specific willow genotypes. In addition to greater yield at Belleville, there was also greater variation in yield at Belleville compared with Tully (Table 4). This may be partially due to the blocking effect at Belleville. The field design for Belleville positioned block four on the west side of the field trial, which received a high amount of wind and snow damage due to its proximity to Lake Ontario, reducing total yield for

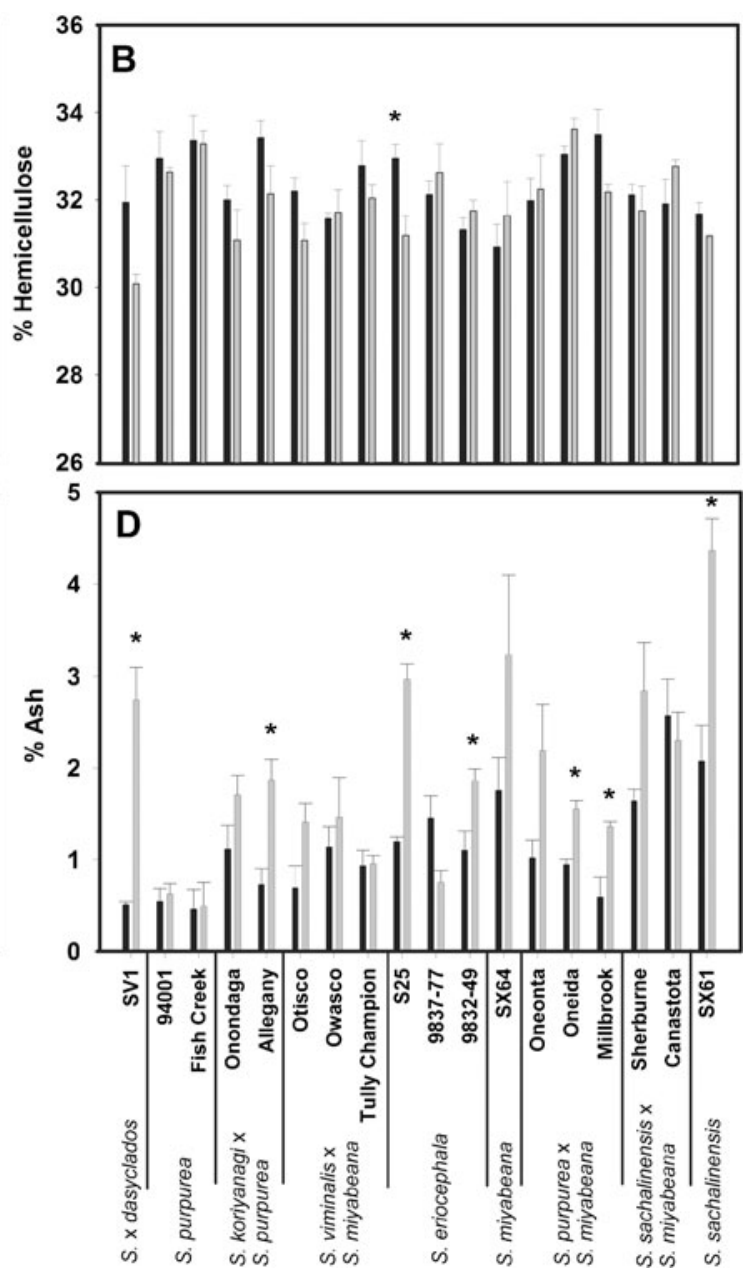

indicate significant differences between the two sites at $p=0.05$. a Cellulose, $\mathbf{b}$ hemicellulose, $\mathbf{c}$ lignin content, and $\mathbf{d}$ ash

that block. This would also explain the high variation among plots in that block (Supplemental Tables 2 and 3). Since shrub willows act as a wind and snow barrier [6], the plots on the east side of block four were more sheltered.

Soil analysis revealed significant differences in $\mathrm{pH}$, aluminum concentration, and nutrient availability (Table 2). The $\mathrm{pH}$ at Tully ( $\mathrm{pH} 5$ ) was much lower than at Belleville with a $\mathrm{pH}$ of 6.5. Due to the lower $\mathrm{pH}$ at Tully, there was reduced P, K, Mg, $\mathrm{Ca}$, and $\mathrm{NO}_{3}{ }^{-}$availability and elevated levels of $\mathrm{Al}$. With better soil conditions at Belleville, it is possible that the plants were less stressed overall, reducing their susceptibility to pest and disease damage. This may explain the weaker correlations between yield and incidence of rust at Belleville, than at Tully. With only two sites, it is difficult to determine the precise environmental changes and conditions that impact yield and the other phenotypic traits examined in this study. Analysis and evaluation of a larger network of yield trials is forthcoming and should provide details about soil conditions and impacts on yield and growth conditions. 
Fig. 5 Wood density (mean $+\mathrm{SE})$ of shrub willow genotypes at harvest after 3 years of growth at Tully and Belleville, NY.

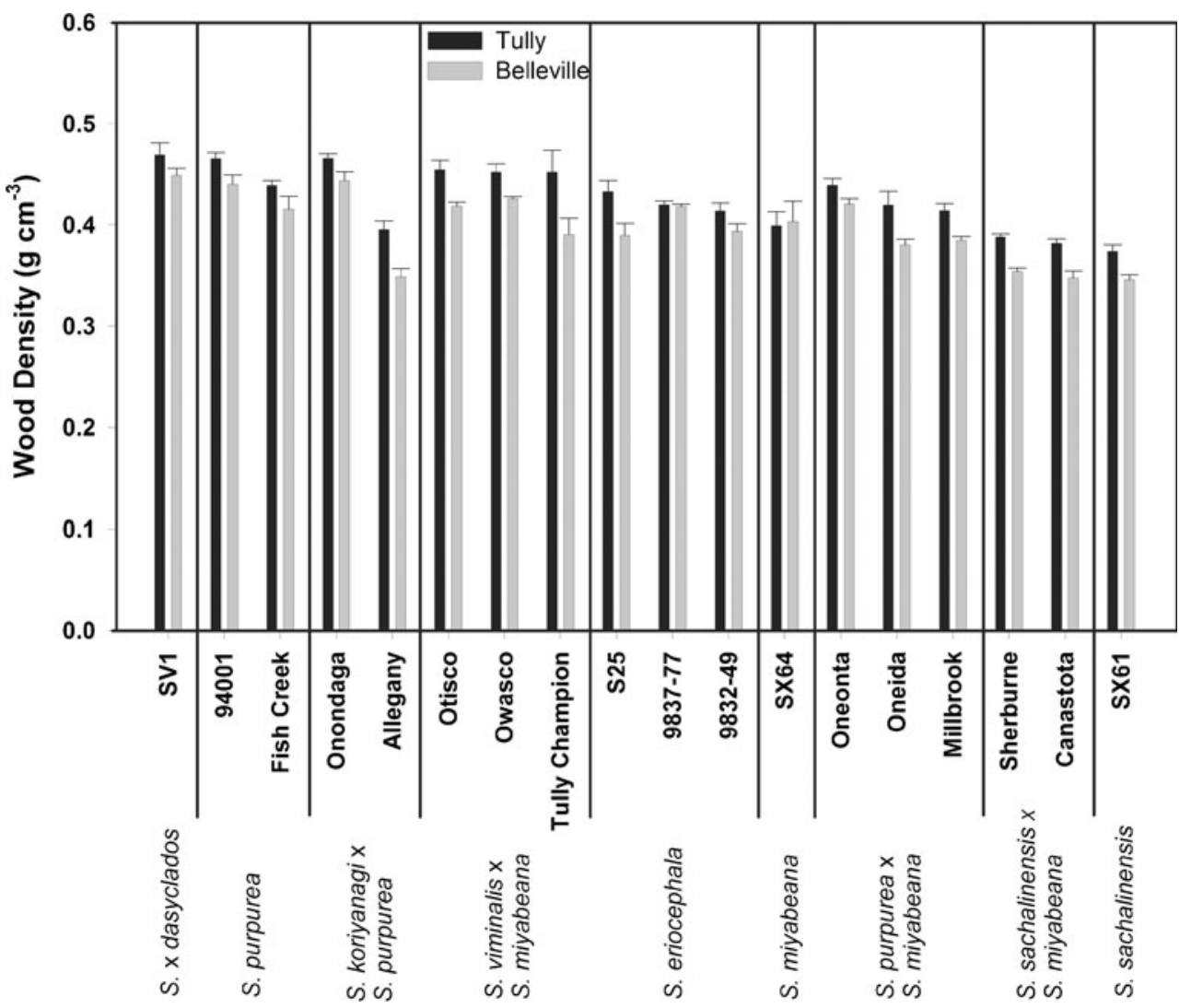

Table 5 Pearson correlation coefficients of phenotypic measurements for all 18 genotypes at each site

\begin{tabular}{|c|c|c|c|c|c|c|c|c|}
\hline Phenotype & $\%$ Hemicellulose & $\%$ Lignin & $\%$ Ash & Density & Yield & Rust 2006 & Rust 2007 & Rust 2008 \\
\hline \multicolumn{9}{|l|}{ Tully } \\
\hline$\%$ Cellulose* & 0.245 & -0.204 & -0.651 & 0.595 & -0.361 & 0.262 & 0.189 & 0.210 \\
\hline$\%$ Hemicellulose & & -0.469 & -0.568 & 0.144 & 0.113 & -0.057 & -0.278 & -0.248 \\
\hline$\%$ Lignin & & & -0.133 & 0.345 & -0.007 & -0.095 & 0.102 & 0.080 \\
\hline$\%$ Ash & & & & -0.700 & 0.078 & 0.005 & 0.081 & 0.098 \\
\hline Density $\left(\mathrm{g} \mathrm{cm}^{-3}\right)$ & & & & & -0.041 & -0.056 & -0.109 & -0.104 \\
\hline Yield $\left(\mathrm{Mg} \mathrm{ha}^{-1}\right)$ & & & & & & -0.888 & -0.880 & -0.859 \\
\hline Rust 2006 (AUDPC) & & & & & & & 0.888 & 0.888 \\
\hline Rust 2007 (AUDPC) & & & & & & & & 0.987 \\
\hline \multicolumn{9}{|l|}{ Belleville } \\
\hline$\%$ Cellulose & -0.005 & -0.268 & -0.663 & 0.665 & 0.136 & 0.212 & 0.358 & 0.175 \\
\hline$\%$ Hemicellulose & & 0.245 & -0.542 & -0.233 & 0.022 & -0.107 & 0.032 & -0.114 \\
\hline$\%$ Lignin & & & -0.385 & 0.077 & 0.133 & -0.264 & -0.392 & -0.221 \\
\hline$\%$ Ash & & & & -0.437 & -0.298 & 0.039 & -0.086 & 0.049 \\
\hline Density $\left(\mathrm{g} \mathrm{cm}^{-3}\right)$ & & & & & 0.422 & -0.026 & 0.084 & -0.037 \\
\hline Yield $\left(\mathrm{Mg} \mathrm{ha}^{-1}\right)$ & & & & & & -0.582 & -0.304 & -0.569 \\
\hline Rust 2006 (AUDPC) & & & & & & & 0.395 & 0.993 \\
\hline Rust 2007 (AUDPC) & & & & & & & & 0.281 \\
\hline
\end{tabular}

* Since compositional data and ash content were only determined for the first three replicate blocks, all correlations were based on only those three replicates. Significant correlations $(p$ value $\leq 0.05$ ) are indicated in bold 
Rust Incidence and Beetle Damage and Specificity

Among the willow genotypes planted at Tully and Belleville, $S$. eriocephala genotypes were the most susceptible to $\mathrm{Mel}$ ampsora infection (Fig. 2). This corroborates previous studies that have shown that this North American native is susceptible to Melampsora infection [42, 43]. Rust pathotypes and genotype resistance in the UK has been studied, but there is poor understanding of the Melampsora pathotypes affecting willow species in North America [39, 44-47]. Previous studies have shown that Melampsora resistance is highly heritable and has already been exploited in breeding for rust resistance through hybridization with Salix schwerinii [44, 46, 48-50]. Wetter leaves might promote rust inoculation and growth. However, there is no clear relationship between rainfall and rust incidence. Our current study does validate the hypothesis that rust susceptibility varies by species, and in this case, the native North American species, S. eriocephala, was highly susceptible to rust. The non-native species and species hybrids showed much less or no rust. S. purpurea, now naturalized in North America, and its hybrids, had low incidence of rust. Breeding with non-native species should reduce the number of new cultivars susceptible to Melampsora infection.

In the current study, the genotypes identified with the greatest damage from beetle feeding at both sites were 'SV1' and S. eriocephala genotypes 9837-77 and 9832-49 (Fig. 3). 'S25' was less damaged than the other two $S$. eriocephala genotypes. All other genotypes had low levels of damage across both sites, except for $S$. viminalis $\times S$. miyabeana genotypes, which had significantly greater leaf damage at Belleville. 'SV1' was among the highest yielding cultivars at Belleville, in spite of the high beetle feeding observed. Though not practical in commercial production, the application of pesticides to reduce beetle damage could reveal the yield potential of 'SV1' and the degree of impact this damage has on yield.

The beetle damage observed at both sites was most likely due to the exotic Japanese beetle (based on beetle identification in the field) and a lesser extent due to the other willow beetles. Japanese beetles are generalist herbivores that are deterred from feeding on leaves with high levels of phenolic glucoside [51]. S. eriocephala has been characterized as producing little phenolic glucoside in leaves, but instead produces condensed tannins, which could explain its susceptibility to beetle damage observed in this study. The foliar chemistry of 'SV1' has not been studied. Lehrman et al. [52] identified a negative correlation between salicylate concentration in leaves and larval performance of blue willow beetle (Phratora vulgatissima L.). Further studies of the concentrations and heritability of these phenolic compounds in novel hybrids could help elucidate the underlying mechanism of resistance.
Genotypic Variation in Wood Physical Properties

Since efforts have been made to maintain high levels of genetic diversity within the current breeding population of shrub willow, phenotypic variation among the genotypes studied in this analysis was expected to be high. The 18 genotypes used in this analysis by no means captures the amount of variation in the entire willow collection [53] but does provide an in-depth characterization of important phenotypic traits for their utility as a bioenergy crop. Biomass composition in terms of percent cellulose, hemicellulose, and lignin was comparable to what has been observed in natural stands of poplar $[9,20,54]$. In general, there was greater cellulose content in the samples from Belleville, but lignin and hemicellulose content were remarkably consistent between the two sites for most of the genotypes (Fig. 4). A common phenomenon observed in cell wall manipulation has been that a loss in lignin content can be compensated by an increase in polysaccharide content, and the opposite holds true as well $[55,56]$. However, we did not observe any correlation with lignin content and cellulose in this study. An increase in cellulose content is observed in tension wood and has been observed in straight stems in response to other environmental factors such as water availability, soil quality, and nitrogen fertilization $[15,57,58]$. With our results, we can only speculate as to what environmental factor contributed to the cellulose content at the two sites.

Ash content within the willow genotypes was variable across both sites, with significantly greater content observed at Belleville in seven of the genotypes (Fig. 4; Supplemental Table 2). Ash content ranged from $0.5 \%$ to over $4 \%$ (the highest observed at Belleville). For most woody species, the bark portion contains significantly greater levels of ash compared with the wood counterpart [59-61]. Bark proportions and composition vary significantly among shrub willow cultivars $[10,61,62]$ and could have an impact on total ash content in the biomass. In general, low ash content in feedstocks is a highly favorable characteristic and improves wood fuel quality. The S. purpurea genotypes and $S$. viminalis $\times$ S. miyabeana hybrids maintain low ash across both sites and can be considered as having high fuel quality for thermochemical applications. The high ash content observed in specific genotypes at Belleville may be related to nutrient availability in the soil. There was a negative correlation between ash content and both hemicellulose and cellulose at both sites. If most of the ash in the biomass is being contributed by the bark portion, this inverse relationship with polysaccharide content can easily be explained by the fact that willow bark contains significantly less polysaccharides than the woody portion of the stem [10]. Breeding for lower bark content may be beneficial if it provides lower ash content, but consideration to the protective qualities of bark must be made. 
Significantly greater wood density was observed at Tully, compared with Belleville. Studies with populations of various fast-growing Populus species and hybrids have revealed negative relationships between volume growth rate and density $[63,64]$. In Pinus radiata, a strong correlation between wood density and cell wall thickness was observed, in addition to a negative relationship between wood density and radial growth rate [65]. An inverse relationship between fiber cell size and wood density has also been observed, indicating that slower volume growth rates lead to higher density due to a reduction in cell size and an increase in cell wall thickness $[66,67]$. This highlights the need to include density in any early measurements of stem volume when biomass yield is the target trait for selection, since fastvolume growth rates could be offset by lower density. A positive correlation between cellulose content and wood density was observed at both sites (Table 5), but overall, lower wood density was observed at Belleville which also produced greater yields. Density did not correlate with yields in this study, which is similar to results from another field trial of willow at Tully, NY [68]. An increase in cellulose deposition into the cell wall has been associated with thicker cell walls in response to nitrogen fertilization [14]. This could explain a correlation between cellulose and wood density at Belleville, which had greater soil N. High wood density has also been associated with drought conditions and aridity $[67,69]$. The precipitation data for Tully and Belleville indicate that Tully received more rainfall during the 2006 and 2007 growing seasons than Belleville. However, with a lower water table and a soil type characterized by excessive drainage [36], it is likely that water availability at Tully was lower than that at Belleville, resulting in greater wood density due to water-limiting conditions. It is clear that more research needs to be done to evaluate what regulates cell wall thickness, cell size, and wood density and how these parameters may change with respect to environmental changes.

The novel species hybrids generated through breeding, $S$. sachalinensis $\times S$. miyabeana, $S$. viminalis $\times S$. miyabeana, and $S$. purpurea $\times S$. miyabeana, produced impressive yields with strong pest and disease resistance. Differences in yield among the genotypes were highly significant at both locations, Belleville and Tully, with greater biomass production on the Belleville site. These results highlight that early selection of new high-yielding willow cultivars is best performed across multiple sites. Yield was negatively correlated with rust damage. Since the economics of willow production and aim for maximum sustainability of this system will deter growers from applying pesticides, breeding and selection for resistance is imperative for long-term yield improvements. In this study, there were no significant relationships between yield and biomass compositional characteristics or wood density, but these may be revealed through examination of a broader diversity of Salix germplasm. Genotypes with low ash content across both sites were identified, including 'Fish Creek,' which had the greatest yield at Belleville. The strong relationship between cellulose content and wood density is intriguing and warrants further research to gain further insight into cell wall development and wood formation in willow.

Acknowledgments This research was funded partially by the New York State Energy Research and Development Authority (NYSERDA), the United States Department of Agriculture National Institute of Food and Agriculture (USDA NIFA), and the North Central Regional Sun Grant Center at South Dakota State University through a grant provided by the US Department of Energy Office of Biomass Programs. The authors would like to thank Steve Johnson and the Belleville Henderson Central School for hosting a yield trial. Appreciation is also expressed to Ken Burns and Mark Appleby for excellent technical support, the multitude of undergraduate students who helped collect data, make cuttings, and maintain trials, and to Dr. Kerik Cox for assistance in the statistical analysis of the pest and disease data. This work was made possible by the excellent breeding done by Richard Kopp in 1998 and 1999.

\section{References}

1. Christersson L, Sennerby-Forsse L (1994) The Swedish programme for intensive short rotation forests. Biomass Bioenerg 6:145-149

2. Larsson S (1998) Genetic improvement of willow for short-rotation coppice. Biomass Bioenerg 15:23-26

3. Lindegaard KN, Barker JHA (1997) Breeding willows for biomass. Aspects Appl Biol 49:155-162

4. Volk TA, Verwijst T, Tharakan PJ, Abrahamson LP, White EH (2004) Growing fuel: a sustainability assessment of willow biomass crop. Front Ecol Eviron 2:411-418

5. Lin J, Gibbs JP, Smart LB (2009) Population genetic structure of native versus naturalized sympatric shrub willows (Salix; Salicaceae). Am J Bot 96:771-785

6. Volk TA, Abrahamson LP, Nowak CA, Smart LB, Tharakan PJ, White EH (2006) The development of short-rotation willow in the northeastern United States for bioenergy and bioproducts, agroforestry, and phytoremediation. Biomass Bioenerg 30:715-727

7. Smart LB, Volk TA, Lin J, Kopp RF, Phillips IS, Cameron KD et al (2005) Genetic improvement of shrub willow (Salix spp.) crops for bioenergy and environmental applications in the United States. Unasylva 221:51-55

8. Smart LB, Cameron KD (2008) Genetic improvement of willow (Salix spp.) as a dedicated energy crop. In: Vermerris WE (ed) Genetic improvement of bioenergy crops. Springer Science, New York, pp 347-376

9. Studer MH, DeMartini JD, Davis MF, Sykes RW, Davison B, Keller M et al (2011) Lignin content in natural Populus variants affects sugar release. Proc Nat Acad Sci USA. doi:10.1073/ pnas 1009252108

10. Serapiglia MJ, Cameron KD, Stipanovic AJ, Smart LB (2009) Analysis of biomass composition using high-resolution thermogravimetric analysis and percent bark content as tools for the selection of shrub willow bioenergy crop varieties. Bioenergy Res 2:1-9

11. Serapiglia MJ, Cameron KD, Stipanovic AJ, Smart LB (2008) High-resolution thermogravimetric analysis for rapid characterization of biomass composition and selection of shrub willow varieties. Appl Biochem Biotech 145:3-11

12. Serapiglia MJ, Cameron KD, Stipanovic AJ, Smart LB (2012) Correlations of expression of cell wall biosynthesis genes with 
variation in biomass composition in shrub willow (Salix spp.) biomass crops. Tree Genet Genomes 8:775-788

13. Mellerowicz E, Baucher M, Sundberg B, Boerjan W (2001) Unravelling cell wall formation in the woody dicot stem. Plant Mol Bol 47:239-274

14. Pitre FE, Cooke JEK, Mackay JJ (2007) Short-term effects of nitrogen availability on wood formation and fibre properties in hybrid poplar. Trees 21:249-259

15. Pitre FE, Lafarguette F, Boyle B, Pavy N, Caron S, Dallaire N et al (2010) High nitrogen fertilization and stem leaning have overlapping effects on wood formation in poplar but invoke largely distinct molecular pathways. Tree Physiol 30:1273-1289

16. Luo Z-B, Langenfeld-Heyser R, Calfapietra C, Polle A (2005) Influence of free air $\mathrm{CO}_{2}$ enrichment (EUROFACE) and nitrogen fertilisation on the anatomy of juvenile wood of three poplar species after coppicing. Trees 19:109-118

17. Pliura A, Yu Q, Zhang SY, MacKay J, Perinet P, Bousquet J (2005) Variation in wood density and shrinkage and their relationship to growth of selected young poplar hybrid clones. Forest Sci 51:472482

18. Kord B, Samdaliri M (2011) The impact of site index on wood density and fiber biometry of Populus deltoides clones. World Appl Sci J 12:716-719

19. Pliura A, Zhang SY, MacKay J, Bousquet J (2007) Genotypic variation in wood density and growth traits of poplar hybrids at four clonal trials. Forest Ecol Manag 238:92-106

20. Novaes E, Kirst M, Winter-Sederoff H, Sederoff R (2010) Lignin and biomass: a negative correlation for wood formation and lignin content in trees. Plant Physiol 154:555-561

21. Novaes E, Osorio L, Drost DR, Miles BL, Boaventura-Novaes CR, Benedict $C$ et al (2009) Quantitative genetic analysis of biomass and wood chemistry of Populus under different nitrogen levels. New Phytol 182:878-890

22. Fahmi R, Bridgwater AV, Donnison I, Yates N, Jones JM (2008) The effect of lignin and inorganic species in biomass on pyrolysis oil yields, quality and stability. Fuel $87: 1230-1240$

23. Demirbas A (2000) Effect of lignin content on aqueous liquefaction products of biomass. Energ Convers Manage 41:1601-1607

24. Oren R, Ellsworth DS, Johnsen KH, Phillips N, Ewers BE, Maier $\mathrm{C}$ et al (2001) Soil fertility limits carbon sequestration by forest ecosystems in a $\mathrm{CO}_{2}$-enriched atmosphere. Nature 411:469-472

25. Smith JA, Blanchette RA, Newcombe G (2004) Molecular and morphological characterization of the willow rust fungus, Melampsora epitea, from arctic and temperate hosts in North America. Mycologia 96:1330-1338

26. Pei MH, Royle DJ, Hunter T (1993) Identity and host alternation of some willow rusts (Melampsora spp.) in England. Mycol Res 97:845-851

27. Pei MH, Royle DJ, Hunter T (1999) Hybridization in larchalternating Melampsora epitea (M. larici-epitea). Mycol Res 103:1440-1446

28. Ziller W (1974) The tree rusts of Canada. Environment Canada Forestry Service, Ottawa, ON, Canada

29. Dawson WM, McCracken AR (1994) Effect of Melampsora rust on the growth and development of Salix burjatica korso in Northern Ireland. Eur J Forest Pathol 24(1):32-39

30. Kendall DA, Hunter T, Arnold GM, Liggitt J, Morris T, Wiltshire CW (1996) Susceptibility of willow clones (Salix spp) to herbivory by Phyllodecta vulgatissima (L) and Galerucella lineola (Fab) (Coleoptera, Chrysomelidae). Ann Appl Biol 129:379-390

31. Kendall DA, Wiltshire CW (1998) Life-cycles and ecology of willow beetles on Salix viminalis in England. Eur J Forest Pathol 28:281-288

32. Bjorkman C, Hoglund S, Eklund K, Larsson S (2000) Effects of leaf beetle damage on stem wood production in coppicing willow. Agric For Entomol 2:131-139
33. Nordman EE, Robison DJ, Abrahamson LP, Volk TA (2005) Relative resistance of willow and poplar biomass production clones across a continuum of herbivorous insect specialization: univariate and multivariate approaches. Forest Ecol Manag 217:307-318

34. Albrectsen BR, Gutierrez L, Fritz RS, Fritz RD, Orians CM (2007) Does the differential seedling mortality caused by slugs alter the foliar traits and subsequent susceptibility of hybrid willows to a generalist herbivore? Ecol Entomol 32(2):211-220

35. Kopp RF, Smart LB, Maynard CA, Isebrands JG, Tuskan GA, Abrahamson LP (2001) The development of improved willow clones for eastern North America. Forest Chron 77:287-292

36. USDA (2009) Soil Survey Staff, Natural Resources Conservation Service, United States Department of Agriculture. Web Soil Survey. Available online at http://websoilsurvey.nrcs.usda.gov/ accessed 10-6-09

37. McDowell L (1981) Soil survey of Jefferson County, New York. USDA Soil Conservation Service and Cornell University Agricultural Experiment Station

38. TAPPI Standard T 258 om-06 (2006) Basic density and moisture content of pulpwood. In: TAPPI Test Methods 2006. TAPPI Press, Technology Park, Atlanta

39. McCracken AR, Dawson M (1992) Clonal response in Salix to Melampsora rusts in short rotation coppice plantations. Eur J Forest Pathol 22:19-28

40. SAS Institute Inc. SAS 9.1.3 Help and documentation. Cary, NC: SAS Institute Inc., 2000-2004

41. Volk TA, Abrahamson LP, Cameron KD, Castellano P, Corbin T, Fabio E et al (2011) Yields of willow biomass crops across a range of sites in North America. Aspects Appl Biol 112:67-74

42. Roche BM, Fritz RS (1998) Effects of host plant hybridization on resistance to willow leaf rust caused by Melampsora sp. Eur J Forest Pathol 28:259-270

43. Fritz RS, Nichols-Orians CM, Brunsfeld SJ (1994) Interspecific hybridization of plants and resistance to herbivores: hypotheses, genetics, and variable responses in a diverse herbivore community. Oecologia 97:106-117

44. Pei MH, Lindegaard K, Ruiz C, Bayon C (2008) Rust resistance of some varieties and recently bred genotypes of biomass willows. Biomass Bioenerg 32:453-459

45. Karp A, Hanley S, Trybush S, Macalpine W, Pei MH, Shield I (2011) Genetic improvement of willow for bioenergy and biofuels. J Integr Plant Biol 53:151-165

46. Pei MH, Shield I, Macalpine W, Lindegaard KN, Bayon C, Karp A (2010) Mendelian inheritance of rust resistance to Melampsora larici-epitea in crosses between Salix sachalinensis and S. viminalis. Plant Pathol 59:862-872

47. Bayon C, Pei MH, Ruiz C, Hunter T, Karp A (2009) Genetic structure and population dynamics of a heteroecious plant pathogen Melampsora larici-epitea in short-rotation coppice willow plantations. Mol Ecol 18:3006-3019

48. Pei MH, Royle DJ, Hunter T (1996) Pathogenic specialisation of Melampsora epitea var. epitea on Salix. Plant Pathol 45:679-690

49. Cameron KD, Phillips IS, Kopp RF, Volk TA, Maynard CA, Abrahamson LP et al (2008) Quantitative genetics of traits indicative of biomass production and heterosis in 34 full-sib $\mathrm{F}_{1}$ Salix eriocephala families. Bioenergy Res 1:80-90

50. Hanley S, Pei M, Powers S, Ruiz C, Mallott M, Barker J et al (2011) Genetic mapping of rust resistance loci in biomass willow. Tree Genet Genomes 7:597-608

51. Orians CM, Huang C, Wild A, Zee P, Dao MTT, Fritz RS (1997) Willow hybridization differentially affects preference and performance of herbivorous beetles. Entomol Exp Appl 83:285-294

52. Lehrman A, Torp M, Stenberg JA, Julkunen-Tiitto R, Björkman C (2012) Estimating direct resistance in willows against a major 
insect pest, Phratora vulgatissima, by comparing life history traits. Entomol Exp Appl 144:93-100

53. Serapiglia MJ (2009) Variation in biomass composition and regulation of lignocellulosic deposition in shrub willow (Salix spp.) bioenergy crops. Dissertation, State University of New York College of Environmental Science and Forestry, Syracuse, NY

54. Blankenhorn PR, Bowersox TW, Kuklewski KM, Stimely GL, Murphey WK (1985) Comparison of selected fuel and chemical content values for seven Populus hybrid clones. Wood Fiber Sci 17:148-158

55. Sticklen M (2006) Plant genetic engineering to improve biomass characteristics for biofuels. Curr Opin Biotechnol 17:315-319

56. Chen F, Dixon RA (2007) Lignin modification improves fermentable sugar yields for biofuel production. Nature Biotech 25:759-761

57. Kaeiser M (1955) Frequency and distribution of gelatinous fibers in eastern cottonwood. Am J Bot 42:331-336

58. Isebrands JG, Bensand DW (1972) Incidence and structure of gelatinous fibers within rapid-growing Eastern cottonwood. Wood Fiber Sci 4:61-71

59. Adler A, Dimitriou I, Aronsson P, Verwijst T, Weih M (2008) Wood fuel quality of two Salix viminalis stands fertilised with sludge, ash and sludge-ash mixtures. Biomass Bioenerg 32:914-925

60. Lehtikangas P (2001) Quality properties of pelletised sawdust, logging residues and bark. Biomass Bioenerg 20:351-360

61. Tharakan PJ, Volk TA, Abrahamson LP, White EH (2003) Energy feedstock characterizations of willow and hybrid poplar clones at harvest age. Biomass Bioenerg 25:571-580
62. Adler A, Verwijst T, Aronsson P (2005) Estimation and relevance of bark proportion in a willow stand. Biomass Bioenerg 29:102113

63. Blankenhorn PR, Bowersox TW, Strauss CH, Kessler K, Stover LR, Di-Cola ML (1992) Chemical composition of second rotation of Populus hybrid NE-388. Wood Fiber Sci 24:280-286

64. Beaudoin M, Hernandez RE, Koubaa A, Poliquin J (1992) Interclonal, intraclonal and within-tree variation in wood density of poplar hybrid clones. Wood Fiber Sci 24:147-153

65. Cato S, McMillan L, Donaldson L, Richardson T, Echt C, Gardner R (2006) Wood formation from the base to the crown in Pinus radiata: gradients of tracheid wall thickness, wood density, radial growth rate and gene expression. Plant Mol Bol 60:565-581

66. Jacobson AL, Pratt RB, Ewers FW, Davis SD (2005) Do xylem fibers affect vessel cavitation resistance? Plant Physiol 139:546556

67. Martinez-Cabrera HI, Jones CS, Espino S, Schenk HJ (2009) Wood anatomy and wood density in shrubs: responses to varying aridity along transcontinental transects. Am J Bot 96:1388-1398

68. Tharakan PJ, Volk TA, Nowak CA, Abrahamson LP (2005) Morphological traits of 30 willow clones and their relationship to biomass production. Can J Forest Res 35:421-431

69. Hoffmann WA, Marchin RM, Abit P, Lau OL (2011) Hyrdaulic failure and tree dieback associated with high wood density in a temperate forest under extreme drought. Glob Change Biol $17: 2731-2742$ 